\title{
Corruption and Misconduct: A Behavioural Reflection From Investigative Reports Into Local Government
}

\author{
Aquinas J. Purcell \\ CPA Australia, Australia
}

\begin{abstract}
This paper offers a local government perspective on the behavioural factors which can be the precursors for corruption and misconduct and those factors which can prevent corruption and misconduct. The investigation centred on corruption and misconduct evidenced from local government investigation reports in Australia, New Zealand and the United Kingdom. A corruption and misconduct taxonomy was developed and the role of the audit committee in the oversight of corruption and misconduct allegations in local government was empirically tested. The empirical findings indicated low support for an audit committee managing corruption and misconduct allegations. The qualitative research found that a robust culture of zero tolerance of corruption and misconduct was one of the best ways to keep a council honest.
\end{abstract}

\section{Keywords}

Corruption, misconduct, public sector, Australia, New Zealand, United Kingdom

\section{Background}

Local government is the third tier in the Australian federal system: the Commonwealth, six state and two territory governments. The 79 municipal councils in Victoria have annual revenues of \$A6.6 billion and combined recurrent and capital expenditures of \$A7.6 billion (Municipal Association of Victoria 2013a, 2013b). Governance in local government has similarities to corporate governance (Australian Stock Exchange 2007) but can be complicated by a party political dimension, constituents' 'wants' and any personal agendas of councillors or officers.

\section{Introduction}

In this presentation, the terms corruption, fraud and misconduct are clarified. It is noted that the perpetrators of corruption, fraud and misconduct in local government can be internal or external to the council, for example, an individual acting alone, individuals acting within with groups or groups operating against the interests of council.

Copyright (C) 2014 Victoria University. This document has been published as part of the Journal of Business Systems, Governance and Ethics in both online and print formats. Educational and non-profit institutions are granted a nonexclusive licence to utilise this document in whole or in part for personal or classroom use without fee, provided that correct attribution and citation are made and this copyright statement is reproduced. Any other usage is prohibited without the express permission of the publisher.
Fraud, corruption and misconduct

Transparency International (2012) stated that corruption is 'the abuse of entrusted power for private gain. It hurts every-one who depends on the integrity of people in a position of authority'. One of their main precepts is that corruption flourishes in 
secrecy, for which the antidote is transparency. Fraud on the other hand, is an 'intentional act by one or more individuals among management, those charged with governance, employees, or third parties, involving the use of deception to obtain an unjust or illegal advantage' (Auditing and Assurance Standards Board 2011:10). This might seem like a distinction without a difference, but fraud generally pertains to obtaining property by deception or by a financial advantage as well as, the creation and the use of false documents. Corruption and misconduct has a broader remit as local government has discretionary powers within their decision-making processes which can act as an enabler for: bribery; conflict of interest; inappropriate development and planning applications; misuse of council resources; partiality and personal interests in procurement and tendering.

The terms 'corruption' and 'misconduct' can sometimes be used interchangeably for example, Gerasimova (2008:223) described corruption as the exercising of 'legitimate discretion for improper reason' and the Independent Commission Against Corruption (ICAC) (2008:1) defined corruption, and misconduct as 'the dishonest or partial behaviour, misuse of information, or breach of trust by a public sector employee, which if proved could amount to a crime or a disciplinary offence'. ICAC (2008:1) considered that corruption extended to the 'conduct of a person, which adversely affects, or could affect, the exercise of an official function by public officials'. Excluding any personal ramifications associated with an individual's corrupt or misconduct misbehaviours, the implication for councils is that their integrity and reputation can be either impacted by proven corruption or tainted by the perception of corruption. This can result in public confidence, financial loss and poor staff morale. There is a need to better understand what can be the causes of corruption and misconduct in order to find ways to reduce their incidence.

\section{$\underline{\text { Perpetrators }}$}

Whilst corruption and misconduct in local government may be a function of motive, opportunity and rationalisation (Wells 2007:91) from the perpetrators perspective, there can be 'the personality correlates of fraud' (Krambia-Kapardis 2001:42) which she summarised as psychological for example: large ego, low self-control, low self-esteem, lying, lack of anxiety and empathy, indifference of the consequence of one's behaviour and impulsivity, and sociological: 'one's associates being part of a criminogenic corporate culture', the ability to neutralise guilt and being prepared to exploit opportunities (Krambia-Kapardis 2001:42-43). We consider that these antecedent factors can influence or act as 'enablers' (Lewin 1951) for the perpetrators, for example, Robbins (2003) noted the influences of: motivation, personality, emotions, job satisfaction, work stresses and personal stresses. For groups, he suggested the influences of group dynamics, clique behaviours, communication, power, conflict, culture, group processes, decision making and inter group behaviours. The mayor and the chief executive should be conscious of the pervasive nature of a negative organisational culture (Lagan 2005a 2005b) sub-cultures, power, conflict, intraorganisational politics and the party political dimension.

\section{$\underline{\text { Cost }}$}

The KPMG (2013:6) Australian and New Zealand biennial bribery and corruption survey for the years 2010-2012 reported that fraud had cost the respondents at least \$A373 million in the last two years increasing from \$A105 million in 1997. Whilst it was difficult to quantify the total cost due to undetected and unreported frauds, KPMG (2013:19) reported that the major public sector fraud categories were tendering, cash and payroll with four reported corruption incidents representing 30\% by value of all incidents (KPMG 2013:19). They found that the major two reasons for the prevalence 
of corruption were the lack of senior management's commitment to ethical conduct and the 'inherently unethical nature of the industry in which the organisation operates' (KPMG 2013:36). Whilst there can be some mechanisms in place to investigate corruption and misconduct for example, the auditor-generals and the anti-corruption bodies, these mechanisms cannot necessarily guarantee that actions within each council will be taken to prevent corruption and misconduct. Prenzler \& Faulkner (2010:257) stated that: 'anticorruption commissions in Australia do not have the power to take disciplinary action against holders of public office when they believe disciplinary action is warranted' which was supported by Purcell (2012a:144) who stated that investigative agency reports may not meet the evidentiary hurdle for subsequent criminal prosecutions.

\section{Possible explanations?}

In explaining corruption and misconduct we were influenced by Marnet (2008) who considered that the focus should be on managerial behaviours themselves, the behavioural traits of individuals not observing accepted societal norms, the tendency of regulators to concede or acquiesce towards corporate misdeeds and the 'socio-psychological effects of group decision-making on judgement and decision quality' (Marnet 2008:9). The 'correlates of criminal behaviour' (Krambia-Kapardis 2001:43) complemented Marnet (2008:97) who stated that 'individuals vary in degree to which they are susceptible to various bias, self-control problems, and temporal inconsistencies'. He further stated that individuals may not act consistently 'when they face choices under uncertainty and may instead vary in their responses depending on situation, context and mood'.

In relation to group behaviours Marnet (2008:97-156) noted the influences of the nature of bias, belief perseverance, loss aversion, escalation of commitment, group-think, sub-optimal monitoring and adverse risk perceptions. These factors may also contribute to an environment that is conducive to corruption, fraud and misconduct to occur, such that, they are surreptitiously inculcated into individual and group behaviours. We concur with Marnet (2008) that the focus should be on managerial behaviours themselves, the behavioural traits of individuals not observing accepted societal norms, the tendency of regulators to concede or acquiesce towards corporate misdeeds and the 'socio-psychological effects of group decision-making on judgement and decision quality' (Marnet 2008:9). These behavioural corruption and fraud precursor conditions together with the motivations for fraud for example, greed, lifestyle, personal financial pressure, gambling and substance abuse (KPMG: 2013:25) were the catalyst to reflect upon the behavioural antecedents for corruption and misconduct in local government. We were influenced by Friedrichs (1996:241) who considered that all explanations of white collar crime have a basic proposition of aberrant human behaviour and that the 'ultimate complexity and diversity of white collar crime precludes the possibility of any single comprehensive theory or explanatory scheme'. We have taken an organisational behavioural perspective because 'to understand the social embeddedness of deviant and criminal behaviour it is essential to grasp that the business organization is the weapon, the means, the setting, the rationalization, the offender, and the victim' (Punch 1996:214).

We consider that a behavioural perspective can provide a prism through which corruption and misconduct in local government can be more effectively understood (Purcell 2012a, 2012b). We have reflected on corruption and misconduct from an organisational behavioural perspective (Gettler 2005a; Long 2008; Marnet 2008; Punch 1996) as compared to compliance and an individual's perspectives (Friedrichs 1996; Cavaiola \& Lavender 2000) and consider that this provides a way of understanding the preconditions for corruption and misconduct to occur. 


\section{Literature review}

Sampford, et al. (2006:1) considered that corrupt payments can influence public policy choices and decisions by officials. They believed that corruption and misconduct should be investigated, not for the sake of morality, but because society paid the price for corruption in one way or another.

Corruption and misconduct can be evaluated from the perspective of official corruption for example, bureaucratic and political corruption and the misuse of public power for pecuniary profit (Gerasimova 2008:224) and occupational fraud (corrupt conduct, asset misappropriation and fraudulent statements) (Association of Certified Fraud Examiners 2010; Wells 2007, 2004).

\section{Aetiology of fraud}

Krambia-Kapardis (2001) used the term 'aetiology' of fraud to categorise the source of white-collar crime. Some contributors are detailed in Figure 1 (Krambia-Kapardis, 2001; Weisburd, Waring \& Chayet, 2001). Some of the literature had a sociological or psychiatric origins (Clarke 2005; Gottschalk 2010; Griffin \& O’Leary-Kelly 2004; Griffin, O’Leary-Kelly \& Collins 1998; Kets de Vries 2001, 1991; Punch 1996) although the Association of Fraud Examiners (2010); Wells (2007, $2004)$ and KPMG $(2013,2010,2008)$ provided recent data in relation to the incidence of fraud.

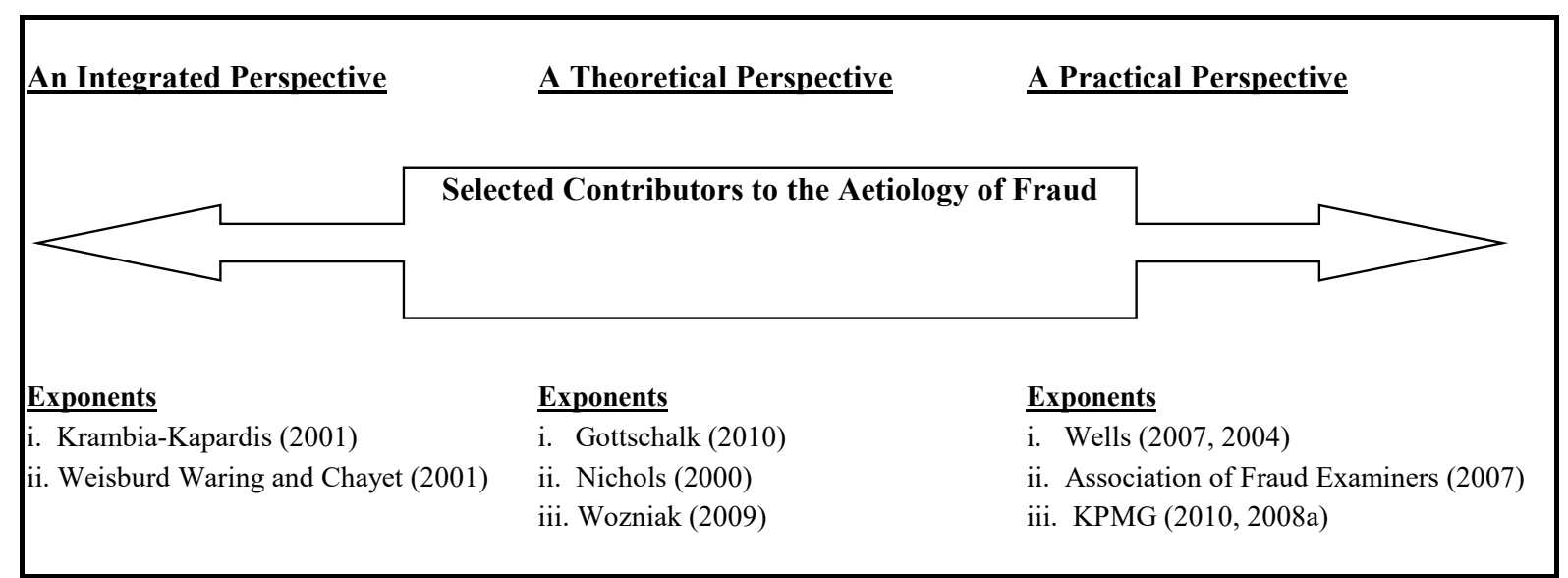

Figure 1 Select contributors to the aetiology of fraud

Krambia-Kapardis (2001) considered that criminal behaviour can be correlated with an offender's personality and situational factors; and these factors can be present in fraud offenders. She considered that it was important for auditors to undertake a comprehensive fraud assessment risk of the companies they audit, based in part on 'red flags' (KPMG 2013:13) and the relationship between 'different industries, different irregularities, different ways that alerted auditors and different audit procedures that appear to detect them' (Krambia-Kapardis 2001:167). Weisburd et al. (2001:3) contradicted the notion that white-collar offenders were generally one-off offenders and noted that offenders had 'multiple contacts in the criminal justice system'. They concluded that repeat offenders presented a mixture of traits associated with deviance and conformity, but as they were white-collar criminals, they had characteristics associated with social stability and achievement. 
Gottschalk (2010) provided a synthesis of the prevailing behavioural, organisational and managerial theories associated with criminality. This had some similarities to a meta-analysis, but was more a description of the literature than a critique. Nichols (2000) analysed similarities and differences between the perception of criminologists and management theorists in relation to white-collar crime. He noted that both groups considered white-collar crime to be serious and that both groups had placed an increased emphasis on white-collar crime over the past two decades. Wozniak (2009) examined white-collar crime from the perspective of institutional structures. He argued that there was a tendency in the criminology literature to explain emerging patterns of crime by referring to dysfunctional families or individuals, rather than dysfunctional social structures. From a fraud investigators' perspective, Wells (2007) categorised fraud by topic and types of schemes and the Association of Fraud Examiners (2010) provided an American perspective on the incidence of whitecollar crime, while KMPG $(2013,2010,2008)$ offered an Australian perspective. Their contribution was the currency of source material obtained from the periodic business surveys: annually for the Association of Fraud Examiners and biennially for KPMG.

\section{Misconduct related factors}

Berlinski (2009) stated that corruption was the 'cancer of economics, with all that metaphor implies' and it was 'enigmatic, poorly understood, hydra-headed, deadly and often hidden until it is too late', (Berlinski 2009, p. 81). By way of parallel, Chang and Golden (2007) examined electoral elections in forty democratic countries in the 1990s and concluded that corruption became less severe as elections were more open, whereas corruption increased where there was closed proportional representation and interference in the political processes. Electoral dishonesty is a reputation risk for councils and can contribute to an unethical and illegal culture which can be pervasive. Brimbank City Council (Ombudsman, Victoria 2009a), Greater Dandenong Council (Reilly 2009) and Whitehorse City Council (Bachelard 2009; Lowe 2010) provided a Victorian perspective to Chang and Golden (2007) which related in part to the party-political machinations, alleged vote rigging and alleged interference in the processes of council(s). The alleged inclusion of dummy candidates in the Whitehorse City Council election in 2005 was subsequently dismissed in the County Court in October 2010, (Lowe 2010, Bachelard 2009). Johnson (2008) focused on the relationship between corruption and the democratic process and the ability to disentangle them and stated that corruption was entangled 'in the political, social and economic landscape in which it operates' (Johnson 2008:371). She considered that corruption cannot be addressed in isolation from these conditions and that it had 'a corrosive and widespread effect on the quality of life of its citizenry' (Johnson 2008:372). For the citizens of the City of Port Phillip (Ombudsman, Victoria 2009b) and the City of Ballarat (Inspector of Municipal Administration 2008) Johnson's observations would appear to be prophetic. Given the above observations on the type of environment where it is most likely to occur, it is important to turn our attention to a behavioural perspective of the antecedent conditions for corruption and misconduct to occur.

\section{Behavioural perspective}

A behavioural perspective can reflect upon an individual's response to the opportunity to engage in corrupt behaviours and the organisational culture for an individual's behaviour to occur. Andreoli and Lefkowitz (2009) considered that organisations with ethical policies, practices and leaders set a positive example of ethical behaviours which contribute to the environment where misconduct could be predicted. Should there be a change in the environment ethical behaviours may be impacted. We suggest that a positive and ethical culture in a council together with strong adherence to internal 
controls increases the ability to detect and prevent corruption, fraud and misconduct, notwithstanding the perpetrators' motives, opportunity and rationalisation. Hodgkinson (1997) examined the changes in the public sector in the 1990s in the United Kingdom in terms of the mode of service delivery and marketization and considered that these were part of the contributing rationale for corruption and misconduct to occur. This was similar to Punch (1996:214), who argued that organisations were the means and the victim, notwithstanding that it was an individual or a group of people who perpetrated corrupt conduct. Hodgkinson (1997:33) considered that the 'marketised public sector' was a state of tension and that it 'creates a hiatus in systems of control and accountability within which the opportunities and incentives for corruption abound'. These tensions in the public sector were also alluded to by Adcroft and Willis (2005); Willis (2004) and Wilson (2003). Hodgkinson (1997) considered that corruption should be examined in the context of systematic or structural corruption explanations similar to the explanations by Punch (1996) and Gobert and Punch (2003).

Punch (1996:213) considered that business was criminogenic and that understanding crime and business 'lies in recognising the structure that the business environment gives to misconduct, both in terms of opportunities, and how misconduct is managed'. He did not believe in a criminological model of fraud and concluded that any attempts to explain fraud 'merely generates platitudinous generalizations' (Punch 1996:244). Gobert and Punch (2003) argued instead for a multi-causal explanation of corruption and misconduct with contingent, situational conditions playing an important role in individual cases. Griffin and O'Leary-Kelly (2004:4) considered organisational dysfunctional behaviour to be "motivated behaviour by an employee or group of employees that has negative consequences for an individual within the organization, another group of individuals within the organization, or the organisation itself'. Gettler (2005a, 2005b) applied the medical term 'psychoses' in a metaphoric sense to the dysfunctionality of organisations. Gettler (2005b:25) cited Bion (1961) in relation to warning signs from dysfunctional groups and stated that Finkelstein (2003) validated the patterns of destructive behaviour in his study of corporate collapses:

Clarke (2005) considered that a fraudster may not necessarily be a sociopath and jumping to such conclusions cannot be substantiated without evidentiary based practice. O'Malley (2002) and Friedrichs (1996) affirmed the conclusions of Sutherland (1961), that is, psychobiological and pathological explanations for white-collar crime have generally been excluded by criminologists as an explanation for white-collar crime. O'Malley (2002:2) argued 'those criminals are people whose environment provide an excess of definitions favourable to crime' which affirmed the argument of Clarke (2005:114). The interpretations of O'Malley (2002), Friedrichs (1996) and Clarke (2005) accorded with Coleman (1994:361), who considered that the motivation and opportunity for whitecollar crime to occur are 'separately interwoven and any successful theory of white-collar crime must take that fact into account'. Price (2000:177) supported Coleman (1994) in relation to ethical failures and stated that in relation to ethical failures of leadership, 'we are often disposed to look for an explanation of the leader's behaviour, not an analysis of the moral status of what was done'.

The Institute of Internal Auditors and KPMG Fraud Survey (KPMG 2008:20) used the term, 'red flags', which are 'early warning signs of possible fraud'. Krambia-Kapardis (2001:51) considered that a disadvantage of a 'red flag' was that it focused attention on cues and potentially limited an investigator from observing other conditions. Clarke (2005:77-101) expanded the notion of 'organisational indicators to include pathological behaviours by a manager or staff member, for example, manipulative, unethical, shallow and parasitic actions, staff bullying and a desire for power and control'. The KPMG Fraud Survey (KPMG 2013:30, 2008:20) noted that 21\%-22\% of respondents in the two surveys indicated that the warning signs of fraudulent activity (KPMG 2013:13) were ignored. 
Corruption and misconduct generally requires two or more parties to consummate the act, for example, councillors using their positions to promote their interests or the interests of other parties (Inspector of Municipal Administration 2008) and usurping planning delegations (Inspector of Municipal Administration 2006; Ombudsman, Victoria 2007). Even when corruption and misconduct can be identified, it is difficult to have a clear picture. Perry (2001:7) noted that one should be careful in trying to estimate the levels of corruption and misconduct in Australia, because the data pertaining to corruption and misconduct via the courts was 'quantitatively uncertain, and qualitatively an imperfect part of the totality'. Andreoli and Lefkowitz (2009:311) noted the limitations of empirical research namely: most of the research was non-quantitative; it is difficult to obtain measures of illegal activities unlikely to be observed by others; and corruption was not amendable to accurate selfreporting.

\section{Method}

The research was undertaken in three parts namely: (1) a review of local government investigation reports in Australia, New Zealand and United Kingdom which were used to formulate a taxonomy of corruption and misconduct; (2) quantitative research formulated from the research question: Do the investigations into local government maladministration and malfeasance enhance governance and the audit committee's effectiveness? and (3) qualitative research.

In the period of 1 January 2000 to 30 September 2009 there were 20 inquiries and investigations into Victorian councils by the: Auditor-General, Victoria, (three investigations); Local Government Victoria, (eight investigations); and Ombudsman, Victoria, (nine investigations) (Table 1). Twenty inquiries, in nearly 10 years in 79 councils is a small number, and we reviewed another 64 local government inquiry reports from New South Wales, Queensland, Western Australia, New Zealand and United Kingdom as a further point of reference and comparison and to increase the number of councils being studied (Table 1). 
Table 1

Investigation Reports into Local Government in the Period 2000 - 2009

\begin{tabular}{|c|c|c|}
\hline State & Investigation Agency & Number \\
\hline Victoria & $\begin{array}{l}\text { - } \\
\text { - } \quad \text { Localitor-General, Victoria } \\
\text { Planning and Community Development) } \\
\text { Ombudsman, Victoria }\end{array}$ & $\begin{array}{c}3 \\
\text { (Note 1) } \\
8 \\
9\end{array}$ \\
\hline New South Wales & $\begin{array}{ll}\text { - } & \text { Department of Local Government, New South } \\
\text { Wales } \\
\text { - } & \text { ICAC }\end{array}$ & $\begin{array}{l}10 \\
13\end{array}$ \\
\hline Queensland & $\begin{array}{ll}- & \text { Local Government, Queensland } \\
\text { - } & \text { Crime and Misconduct Commission }\end{array}$ & $\begin{array}{c}1 \\
9 \\
\text { (Note 2) }\end{array}$ \\
\hline Western Australia & $\begin{array}{l}\text { - } \\
\text { Department of Local Government and Regional } \\
\text { Development } \\
\text { Corruption and Crime Commission }\end{array}$ & $\begin{array}{c}4 \\
4 \\
4 \text { (Note 3) }\end{array}$ \\
\hline New Zealand & Controller and Auditor-General New Zealand & 6 \\
\hline United Kingdom & Audit Commission, United Kingdom & 17 \\
\hline & Total Number of Reports & 84 \\
\hline
\end{tabular}

From reports from the Auditor-General, Victoria, Local Government Victoria, Ombudsman, Victoria, Department of Local

Government, New South Wales, ICAC, New South Wales Local Government, Queensland, Crime and Misconduct Commission,

Queensland, Department of Local Government and Regional Development, Western Australia, Corruption and Crime Commission

Western Australia, Controller and Auditor-General New Zealand and Audit Commission, United Kingdom.

Notes:

Note 1: The reported number of investigation reports has excluded consideration of the financial and performance in local government.

Note 2: The Crime and Misconduct Commission was established in 1991, and since 2000 has undertaken 9 investigations into local government.

Note 3: The Corruption and Crime Commission was established in 2004. 
This number was reduced to forty-six reports selected on the basis of: similarities in the ambit of the council's responsibilities; and the availability of investigation reports to complement the corruption and misconduct taxonomy developed in this research. The research questionnaire was based on a 'factorial design' to measure the perceptions of Victorian mayors, chief executives and chairs of the audit committee with the results compared with the perceptions of the committee members of the Local Government Shires Association of New South Wales (LGSANSW) and board members of the Municipal Association of Victoria (MAV). A response rate of 36\% from 282 questionnaires provided the quantitative data to compare and contrast results from councils. Following the quantitative research, interviews were held with a mayor, a councillor, two chief executives, two directors of corporate services, an auditor and three chairs of audit committees to explore the low response rate to some questions from the quantitative research and the relevance of research outcomes for their councils.

\section{Findings}

The review of the local government investigation reports from Australia, New Zealand and the United Kingdom provided examples of corruption and misconduct, but did not fully explain the behavioural reasons that allowed the fraud, corruption and misconduct incidents to occur. The investigation reports detailed in Table 2 and Appendix 1 can be interpreted within the following taxonomy developed in this research, namely: council maladministration, financial mismanagement, corrupt or unethical conduct by councillors or staff and breaches of statutory powers. Breaches of statutory powers in planning powers also can include political interference by councillors, politicians and selfinterested parties.

Table 2 Summary of Local Government Investigations in Victoria, New South Wales, Queensland, Western Australia, New Zealand, and the United Kingdom

\begin{tabular}{|l|c|c|c|c|}
\hline \multicolumn{1}{|c|}{ Category } & Victoria & $\begin{array}{c}\text { New South Wales, } \\
\text { Queensland and } \\
\text { Western Australia } \\
\text { (Note 1) }\end{array}$ & $\begin{array}{c}\text { New Zealand and } \\
\text { United Kingdom } \\
\text { (Note 3) }\end{array}$ & Sub-Total \\
\hline $\begin{array}{l}\text { Council governance and } \\
\text { maladministration }\end{array}$ & 2 & 2 & 6 & 10 \\
\hline $\begin{array}{l}\text { Financial } \\
\text { mismanagement }\end{array}$ & 3 & 3 & 2 & 20 \\
\hline $\begin{array}{l}\text { Corrupt or unethical } \\
\text { conduct by councillors } \\
\text { or staff }\end{array}$ & 4 & 14 & 1 & 5 \\
\hline $\begin{array}{l}\text { Breach of statutory } \\
\text { powers }\end{array}$ & 4 & nil & 14 & 46 \\
\hline \multicolumn{1}{c|}{ Sub-Totals } & 13 & 19 & & 2 \\
\hline
\end{tabular}


Note 1: For Victoria, the investigations reports are from the Auditor-General, Ombudsman, Victoria, and the Inspector of Municipal Administration.

Note 2: For local government in New South Wales, Queensland, Western Australia, the investigation reports from the ICAC, Crime and Misconduct Commission, Corruption and Crime Commission and the Department of Local Government.

Note 3: The investigation reports from New Zealand and the United Kingdom are from the Audit-Commission, United Kingdom and the Controller and Auditor-General, New Zealand respectively.

This presentation in Appendix 1 and Table 2 does not suggest that all councils are corrupt, engage in systemic misconduct, or even that the allegations in the investigation reports are proven within a subsequent judicial review process. For example the: (1) allegations into the financial management practices in the Warrnambool City Council (Auditor-General, Victoria 2005); (2) allegations of misconduct in the Douglas Shire Council (Crime and Misconduct Commission (2006), and (3) the funding of a proposed stadium by the Dunedin City Council and the Otago Regional Council (Controller and Auditor-General, New Zealand 2007) were found to be unsubstantiated. Nevertheless, there are some inherent corruption and misconduct risks in local government for example, statutory planning and building control, which stakeholders need to be cognisant of, including the offering and the solicitation of bribes. Table 2 and Appendix 1 provides examples of behaviours in local government which can be perpetrated by councillors, the leadership team of council, employees against the council interests, external parties or a combination of these groups. The relevance of the taxonomy of corruption and misconduct is that it identifies areas of known high risks (Table 2) which can assist councils to effectively focus their attention on preventing and detecting corruption and misconduct to safeguard councils against future incidents. The taxonomy complements the corruption resistance strategies in local government (ICAC 2001) and public sector fraud (KPMG 2013).

The empirical research in relation to the question whether investigations into local government maladministration and malfeasance enhance governance and the audit committee's effectiveness was not supported. The mayors, chief executives and chairs of audit committees of Victorian councils were more satisfied with the existing processes for the management of corruption and misconduct policies than their counterparts the LGSANSW. The responses from board members of the MAV were low in comparison to the LGSANSW and there was a wide range in the standard deviation reflecting a diverse range of views from the mayors, chief executives, chairs, committee members of LGSANSW and the MAV board members. The respondents did not consider that the audit committee was the appropriate forum to receive allegations. Whilst Victorian councils were cognisant of their misconduct and corruption risks and had generally benchmarked their management processes against the internal control deficiencies from the investigative reports, there was no support for an audit committee to actively participate in or oversee whistle-blower or misconduct allegations.

From the qualitative research, the interviewees did not consider that the audit committee had a role to play in the oversight of misconduct or whistleblower allegations. One councillor noted that these matters were generally handled directly by the chief executive or independently by an external investigative agency. One chief executive indicated that if there was an important issue, he would immediately inform the mayor and chair of the audit committee and the councillors and the audit committee at their next meeting. An audit committee chair referred to the council's fraud and 
misconduct policy, and considered that the audit committee would be part of the communication chain albeit, not part of the management or investigative process. He indicated that if the allegations related to the chief executive or a councillor, the audit committee chair may be a conduit to provide oversight of the process although any councillor's misconduct would normally be subject to the processes of a councillor conduct panel under sections 81A-81S of the Local Government Act (1989). A corporate services director stated that having a role for the audit committee in any investigative process could confuse the role of the audit committee as compared to providing oversight of the council's risk management processes. Another corporate services director discussed the inherent corruption and misconduct risks of councils, which can be hidden beneath the surface. He believed that a robust culture within council was one of the best ways of expressing a zero tolerance to corruption and misconduct and provided a safe environment for any issues to be raised. He considered that it was not the role of the audit committee to either investigate or manage the allegations. Another chief executive concurred with these observations and stated that it was always a question of prudence, of where the line was drawn, between advising the audit committee and overburdening the audit committee.

\section{Discussion}

So what do the outcomes from the investigative reports and the empirical research mean for local government? Corruption and misconduct in local government can be a complex and multifaceted phenomenon and no single theory can comprehensively explain all forms of misconduct within the aetiology of fraud. In explaining misconduct in local government one needs to recognise human behaviours in all their intricacies and varieties. Friedrichs (1996:241) stated that 'the ultimate complexity and diversity of white collar crime precludes the possibility of a single comprehensive theory of explanatory scheme'.

One needs to reflect on the levels of theory for example: Krambia-Kapardis (2001), Gottschalk (2010) Nichols (2000), and Wozniak (2009) with the fraud practitioners' perspective (Wells 2007; KPMG 2013, 2010, 2008) as compared to explanations for corruption \& misconduct (Punch, 1996; Griffin \& O'Leary-Kelly, 2004; and Clarke 2005). Whilst greed can be a core motivation to explain corruption and misconduct, the antecedent behavioural conditions for corruption and misconduct to occur and in what circumstances, can be multiple. Overwhelmingly it will be specific to each council in which the corruption and misconduct event occurs. For example, a council could have an over-controlling leader, staff with passive-aggressive personalities, staff with narcissistic or histrionic personality disorders or other behavioural traits. A practical approach to solving a myriad of organisational problems based on personality traits can be difficult, due in part to their complexity and potentially their interrelationship with other internal and external influences (Clarke 2005). In relation to dysfunctional behaviours in organisations, behaviours and emotions within an organisation can coexist on a number of levels, namely the individual, the group; the council, as well as compliance and stakeholder interactions (Robbins 2003). Organisational dysfunctionality can relate to the toxicity of culture and low emotional intelligence on the part of the leader; however, a consequence of dysfunctionality is its impact upon followers in the organisation (Clarke 2005; Griffin \& O'LearyKelly 2004; Griffin, O’Leary-Kelly \& Collins 1998; Pech \& Slade 2004; Robbins 2003).

Applying some psychological theories to corrupt or dishonest organisations and disgraced leaders retrospectively was simple, yet it was generally impossible whilst an organisation was in the midst of a crisis (Clarke 2005; Gettler 2005b; Griffin \& O'Leary-Kelly 2004; Griffin et al. 1998; Kets de Vries 2001, 1991). Some staff within councils may have limited insights and may have observed various unrelated incidents, but these events and behaviours may not be in context. Even if some staff can 
clearly identify the issues, they may be powerless to influence or implement changes. Whilst it may be possible to generalise about councils sliding into an abyss, it is quite another thing to build a model that accurately predicts council corruption. However, the investigation reports of local government within Australia, namely in New South Wales, Queensland, Victoria, and Western Australia, and abroad, New Zealand and the United Kingdom have been accepted as validating findings of corruption and misconduct, notwithstanding that only a court can determine if the parties involved are guilty or not guilty.

In relation to governance Marnet $(2008,2007,2005,2004)$ considered that some of the literature focused on a quantifiable relationship between measures of corporate performance and solutions to agency problems such as independent directors, external audits and accounting standards. This raises questions about the effectiveness of the conventional approach to monitoring and controlling the behaviours of managers. Marnet (2008) considered that whilst the research had identified some important aspects of the fundamental conflict and tensions between agent and principal, there were some questions as to the relevance of the research in monitoring and controlling managerial performance. He noted that 'numeric variables and models of rational behaviour have a poor record in the detection, prevention, and forecasting of earnings management, and accounting fraud' (Marnet 2008:207).

An outcome from this research and an area of future research relates to the power of culture and subcultures within a council, which can have the ability to hide more than it reveals. Lagan (2005a, 2005b) considered that in its simplest form organisational culture is a set of societal arrangements that needs to be consciously managed, rather than left to chance. This suggests that a culture of a council can cast long shadows that may conceal unspoken and deeply pervasive irregularities, as identified from the investigation reports. These shadows can become manipulated systems with councillors and executives slowly coming adrift from peer and industry norms and this pathological drift may desensitise councillors and executives to the severity of irregularities and its destructive nature within a council.

\section{Conclusion}

What emerges from the review of the investigative reports is that explaining corruption and misconduct in local government can be difficult. To investigate them requires the trust of informants and the ability to have powerful insights with impeccable timing. All this is not possible without the support of councillors and the chief executive, who may or may not be disposed to someone analysing corruption and misconduct risks, particularly if they are not as 'white as snow' themselves. Whilst agency reports are a point of reference to identify corruption or misconduct, there may have been some earlier anecdotal evidence or suspicions of wrongdoing, notwithstanding it may not have met the evidentiary hurdle for a successful criminal prosecution. Also, it can be difficult to identify corruption or misconduct when events are happening within various work groups and subcultures within council.

Thus the investigation reports in local government councils can be partially explained in the broader behavioural context of organisational dysfunctionality, a toxicity of culture, ineffectual leadership and an individuals' unethical response to opportunity and motivation to engage in corruption and misconduct. 


\section{References}

Adcroft, A. and Willis, R. 2005. 'The (Un) intended outcome of public sector measurement', The International Journal of Public Sector Management, 18:5, 386-400.

Andreoli, N. and Lefkowitz, J. 2009. 'Individual and organizational antecedents of misconduct in organizations', Journal of Business Ethics, 85:3, 309-332.

Association of Fraud Examiners, 2010. Report to the Nations on Occupational Fraud and Abuse, available at http://www.acfe.com/uploadedFiles/ACFE_Website/Content/documents/rttn-2010.pdf accessed last 12 February 2012.

Auditing and Assurance Standards Board, 2011. The auditor's responsibilities relating to fraud in an audit of a financial report, Auditing Standard ASA 240, available at http://www.auasb.gov.au/admin/file/content102/c3/Jun11_Compiled_ASA_240.pdf accessed last August 2012.

Auditor-General, Victoria, 2005. Review of Warrnambool City Council Financial Management Practices,

Results of Financial Statements for Agencies with other than 30 June 2005 Balances, Melbourne, available at http://www.audit.vic.gov.au/reports_pm_psa/psa1111html accessed last 15 August 2006.

Australian Stock Exchange, 2007. Corporate Governance Principles and Recommendations, with 2010 Amendments, Second Edition, August, Sydney, available at $\mathrm{http} / / /$ www.asx.com.au/documents/about/cg_principles_recommendations_with_2010_amendment s.pdf last accessed 25 March 2011.

Bachelard, M. 2009. 'ALP staffer facing 42 counts of fraud', The Age, August 2:9.

Berlinski, C. 2009. 'The Dark Side of Corruption', Policy Review, June/July: 71-81.

Cavaiola, A. A. and Lavender, N. J. 2000. Toxic Coworkers: How to deal with dysfunctional people on the job, New Harbinger Publications, Oakland.

Chang, E. C. C. and Golden, M. A. 2007. 'Electoral systems, district magnitude and corruption', British Journal of Political Science, 37:1, 115-137.

Clarke, J. 2005. Working with Monsters How to Identify and Protect Yourself from Workplace Psychopaths, Random House, Sydney.

Coleman, J. W. 1994. The Criminal Elite: The Sociology of White-collar Crime, St Martins Press, New York.

Controller and Auditor-General, New Zealand, 2007. Inquiry into Dunedin City Council and Otago Regional Council's funding of the proposed stadium, Wellington, New Zealand, available at http://www.oag.govt.nz/2007/dunedin-stadium/ accessed last 7 September 2009.

Crime and Misconduct Commission, 2006. Investigation into the Allegations Affecting the Douglas Shire Council, October, Brisbane, Queensland, Australia, available at http://www.cmc.qld.gov.au/data/portal/00000005/content/76435001161924976712.pdf accessed last 25 March 2008.

Friedrichs, D. O. 1996. White-collar Crime in Contemporary Society, Wasworth Publishing Company, Belmont.

Gerasimova, K 2008. 'Can corruption and economic crime be controlled in developing countries and if so, is it cost effective?' Journal of Financial Crime, 15:2, 223-233.

Gettler, L. 2005a. 'From bad timings to bad times', The Sydney Morning Herald, 3 January available at http://www.smh.com.au/news/Business/From-bad-timings-to-badtimes/2005/01/02/1104601236738.html accessed last 12 April 2013.

Gettler, L. 2005b. Organisations Behaving Badly, A Greek Tragedy of Corporate Pathology, John Wiley \& Sons, Queensland.

Gobert, J. and Punch, M. 2003. Rethinking Corporate Crime, Butterworths Lexis Nexis, London.

Gottschalk, P. 2010. 'Theories of financial crime', Journal of Financial Crime, 17:2, 210-222.

Griffin, R. W. and O'Leary-Kelly, A. M. 2004. The Dark Side of Organizational Behaviour, JosseyBass, San Francisco.

Griffin, R. W. O'Leary-Kelly, A. M. and Collins, J.M. 1998. 'Dysfunctional Work Behaviours in

Organizations', in Rousseau, D. M. and Cooper, C. (Eds), 1998, Trends in Organizational Behaviour: 65-8) I nndon Inhn Wilev \& Sone 
Hodgkinson, P, 1997. 'The sociology of corruption, some issues and themes', Sociology, 31:1, 17-35.

Independent Commission Against Corruption. 2008. Corruption Risk Management, Sydney, available at http://www.icac.nsw.gov.au/files/pdf/Corruption_risk_management_web.pdf accessed last 18 December 2008.

Independent Commission Against Corruption. 2001. Corruption Resistance Strategies: Researching risks in local government, available at http://www.icac.nsw.gov.au/index.php?zoom_query=Corruption+Resistance+Strategies\%3A+Res earching + risks + in + local + government $\% 2 C+\& z o o m \_$and $=1 \&$ zoom_per_page $=100 \&$ option $=$ com_z oomsearch\&zoom_sort $=0 \&$ Itemid $=2655$ accessed last 19 April 2013.

Inspector of Municipal Administration, 2008. Investigation into Ballarat City Council, September, Local Government Victoria, Melbourne, available at http://www.dvc.vic.gov.au/Web20/rwpgslib.nsf/GraphicFiles/Investigation+into+Ballarat+City $+\mathrm{C}$ ouncil + pdf $/ \$$ file/Investigation+into+Ballarat + City + Council +-+ Sept +08 .pdf accessed last 20 December 2008.

Inspector of Municipal Administration, 2006. Report on Investigation into Greater Geelong City Council, 25 May 2006, Local Government Victoria, Melbourne, available at http://www.localgovernment.vic.gov.au/web20/rwpgslib.nsf/GraphicFiles/Investigation

GeelongCityCouncil/\$file/InvestigationGeelongCityCouncil.pdf accessed last 21 March 2008.

Johnson, R. A. 2008. 'Disentangling corruption and democracy', The Journal of Social, Political and Economic Studies, 33(3):371-379.

Kets de Vries, M. 2001. The Leadership Mystique, Prentice-Hall, London.

Kets de Vries, M. 1991. Organizations on the Couch, Clinical Perspective on Organizational Behavior and Change, Jossey-Bass, San Francisco.

KPMG, 2013. A Survey of fraud, bribery and corruption in Australia and New Zealand 2012, available at http://www.kpmg.com/au/en/issuesandinsights/articlespublications/fraudsurvey/pages/fraud-bribery-corruption-survey-2012.aspx accessed last 10 April 2013.

KPMG, 2010. Fraud and Misconduct Survey 2010, available at

http://www.kpmg.com/AU/en/IssuesAndInsights/ArticlesPublications/FraudSurvey/Documents/Fraud-and-Misconduct-Survey-2010.pdf accessed last 12 February 2012

KPMG, 2008. Fraud Survey 2008, available at http://www.kpmg.com.au/Portals/0/Fraud\%20Survey\%202008.pdf accessed last 22 August 2009.

Krambia-Kapardis, M. 2001. Enhancing the Auditor's Fraud Detection Ability: An Interdisciplinary Approach, Peter Lang Publishing, Frankfurt.

Lagan, A. 2005a. A View from the Top, Business Ethics and Leadership, KPMG, available at http://www.kpmg.com.au/Portals/0/rasbas_view-from-the-top200510.pdf accessed last 13 February 2005.

Lagan, A. 2005b. 'Boards must put backbone into their tone at the top', The Age, 10 November: 10.

Lewin, K. 1951. Field Theory in Social Sciences, Harper Row, New York.

Long, S. 2008. The perverse organisation and its deadly sins, Karnac Books Ltd, London.

Lowe, A. 2010. 'Fraud Charges dismissed: Ex Mayor has no case to answer', The Age, 12 October, available at http://www.theage.com.au/victoria/fraud-claims-dismissed-ex-mayor-has-no-case-toanswer-20101012-16gsg.html accessed last 12 October 2010.

Marnet, O. 2008. Behaviour and Rationality in Corporate Governance, Routledge (Taylor and Francis Group), Abingdon.

Marnet, O. 2007. 'History repeats itself: The failure of rational choice models in corporate governance', Critical Perspectives on Accounting, Spring, 18:2, 191-210.

Marnet, O. 2005. 'Behaviour and rationally in corporate governance', Journal of Economic Issues, September, 39:3, 613-632.

Marnet, O. 2004. 'Behavioural aspects of corporate governance', Advances in Financial Economics, October, 9:265-286.

Municipal Association of Victoria, 2013a. Victorian Local Government Snapshot, available at http://www.mav.asn.au/about-localgovernment/Related\%20documents Victorian\%20local\%20government\%20snapshot\%20fact $\% 20$ sheet.doc accessed last 31 March 2013. 
Municipal Association of Victoria, 2013b. About local government, available at http://www.mav.asn.au/about-local-government/Pages/default.aspx accessed last 31 March 2013.

Nichols, L T. 2000. 'Constructing white-collar crime: claims in criminology and management education', Business and Society Review, 105:2, 221-246.

O’Malley, P. 2002. Criminology and Fraud, Fraud Investigation Course, La Trobe University, Bundoora, Victoria, Australia.

Ombudsman, Victoria, 2009a. Investigation into the alleged improper conduct of Councillors at Brimbank Council, Melbourne, available at http://www.ombudsman.vic.gov.au/resources/documents /Investigation_into_the_alleged_improper_conduct_of_councillors_at_Brimbank_City_Council_P 1-P1991.pdf accessed last 8 May 2009.

Ombudsman, Victoria, 2009c. A Report of Investigations in the City of Port Phillip, Melbourne, available at http://www.ombudsman.vic.gov.au/resources/documents/A_report of_investigations_into_the_City_of_Port_Phillip.pdf accessed last 13 August 2009.

Ombudsman, Victoria, 2007. Own Motion Investigation into the Policies and Procedures of the Planning Department at the City of Greater Geelong, Melbourne, available at http://www.ombudsman.vic.gov.au/resources/documents/Own_motion_investigation_ into_the_policies_and_procedures_of_the_planning_department_at_the_CGG.pdf accessed last 21 March 2008.

Pech, R. J. and Slade, B. W. 2004. 'Memetic engineering: A framework for organisational diagnosis and development', The Leadership and Organization Development Journal, 25:5, 452-465.

Penzler, T. \& Faulkner, 2010. Towards a model public sector integrity commission, The Australian Journal of Public Administration, 69:3, 251-262

Perry, P. J. 2001. Political Corruption in Australia: A Very Wicked Place, Ashgate Publishing Company, Aldershot.

Price, T. L. 2000. 'Explaining ethical failures of leadership', The Leadership and Organization Development Journal, 21:4, 177-184.

Punch, M. 1996. Dirty Business, Exploring Corporate Misconduct, Analysis and Cases, Sage Publications, London.

Purcell, A. J. 2012a. Effectiveness of Audit Committees in Victorian Local Government, PhD Thesis, Victoria University, Footscray.

Purcell, A. J. 2012b. Corruption and Misconduct in Local Government in Australia: What we know, but can have some trouble understanding and explaining, The IIA Journal, 1:35-40.

Reilly, T. 2009. 'The Mayor, the MP, the council, and the catfight', Sunday Age:9

Robbins S. P. 2003. Organizational Behavior, 10th edition, Pearson Education, New Jersey.

Sampford, C. Shadlock, A. Connors, C. and Galtung, F. (Eds), 2006. Measuring Corruption, Ashgate Publishing Company, Aldershot.

Sutherland, E. 1961. White-collar Crime, Holt, Rinehart \& Winston, New York, In O’Malley, P. 2002, Criminology and Fraud, Fraud Investigation Course, La Trobe University, Bundoora.

Transparency International, 2012. What is corruption? available at http://www.transparency.org/whatwedo?gclid=CMmQoarv27ECFaRMpgod_T4A0w accessed August 2012.

Weisburd D. Waring E. Chayet, E. F. 2001. White-Collar Crime and Criminal Careers, Cambridge University Press, Cambridge.

Wells, J. T. 2007. Encyclopedia of Fraud, Association of Fraud Examiners, 3rd Edition, Austin.

Wells, J. T. 2004. Corporate Fraud Handbook, Prevention and Detection, Association of Fraud Examiners, Austin.

Willis, J. 2004. 'The third way, welfare, work and local governance reform', Environment and Planning A, 36:4, 571-578.

Wilson, D. 2003. 'Unravelling control freakery: Redefining central-local government relations', British Journal of Politics and International Relations, August, 5:3, 317-346.

Wozniak J. F. 2009. 'C. Wright Mills and higher immorality: Implications for corporate crime, ethics, and peacemaking criminology', Crime, Law and Social Change, 51:1, 189-203. 


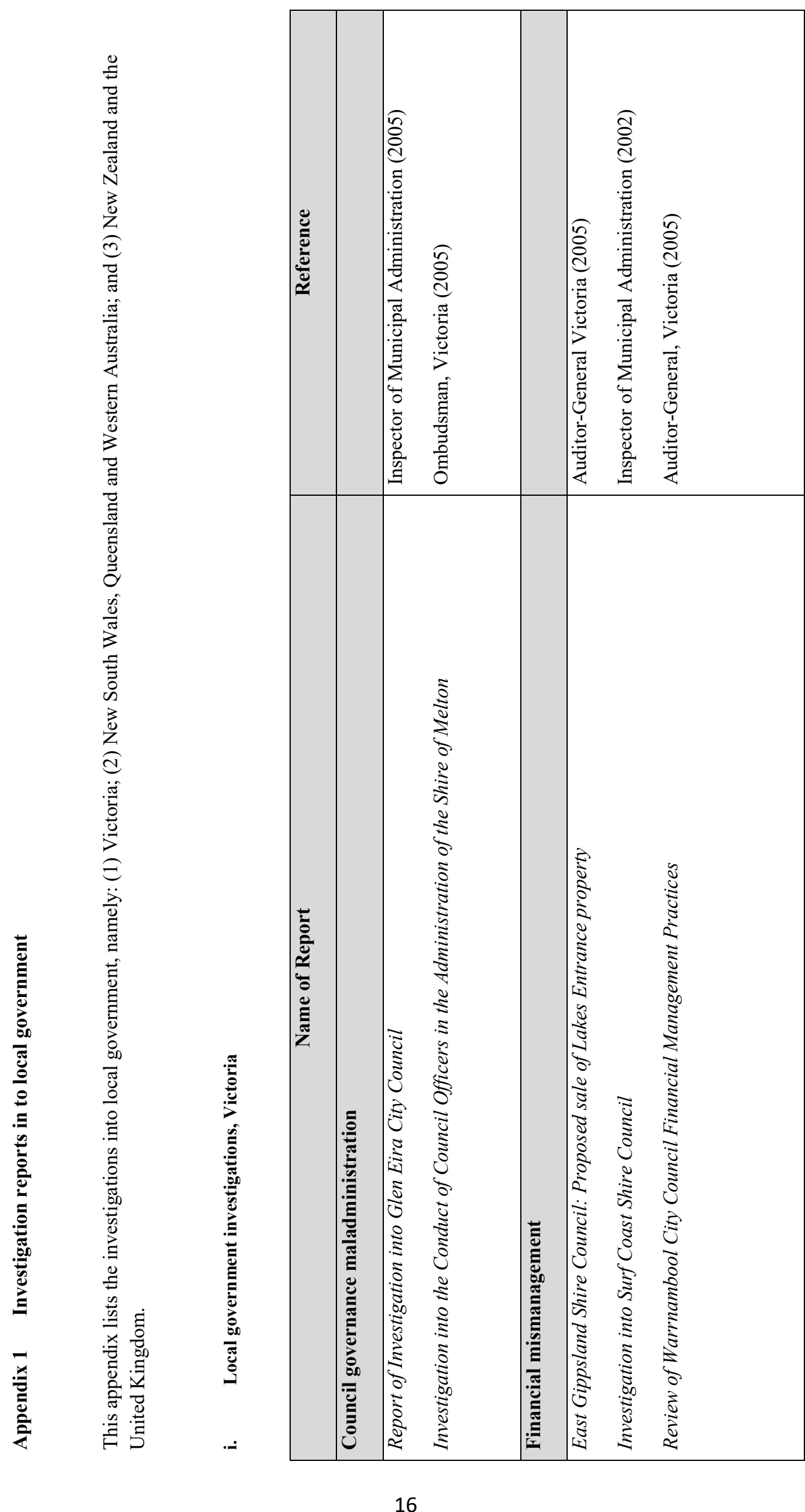




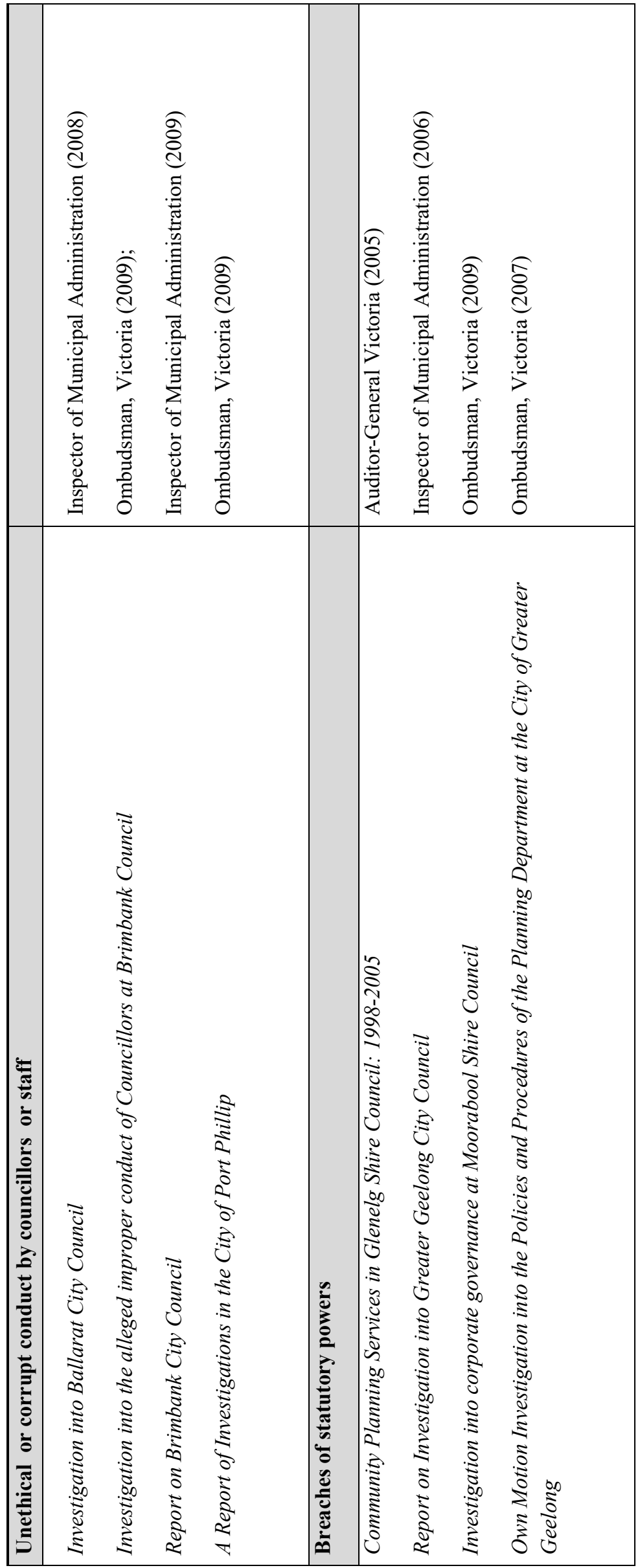




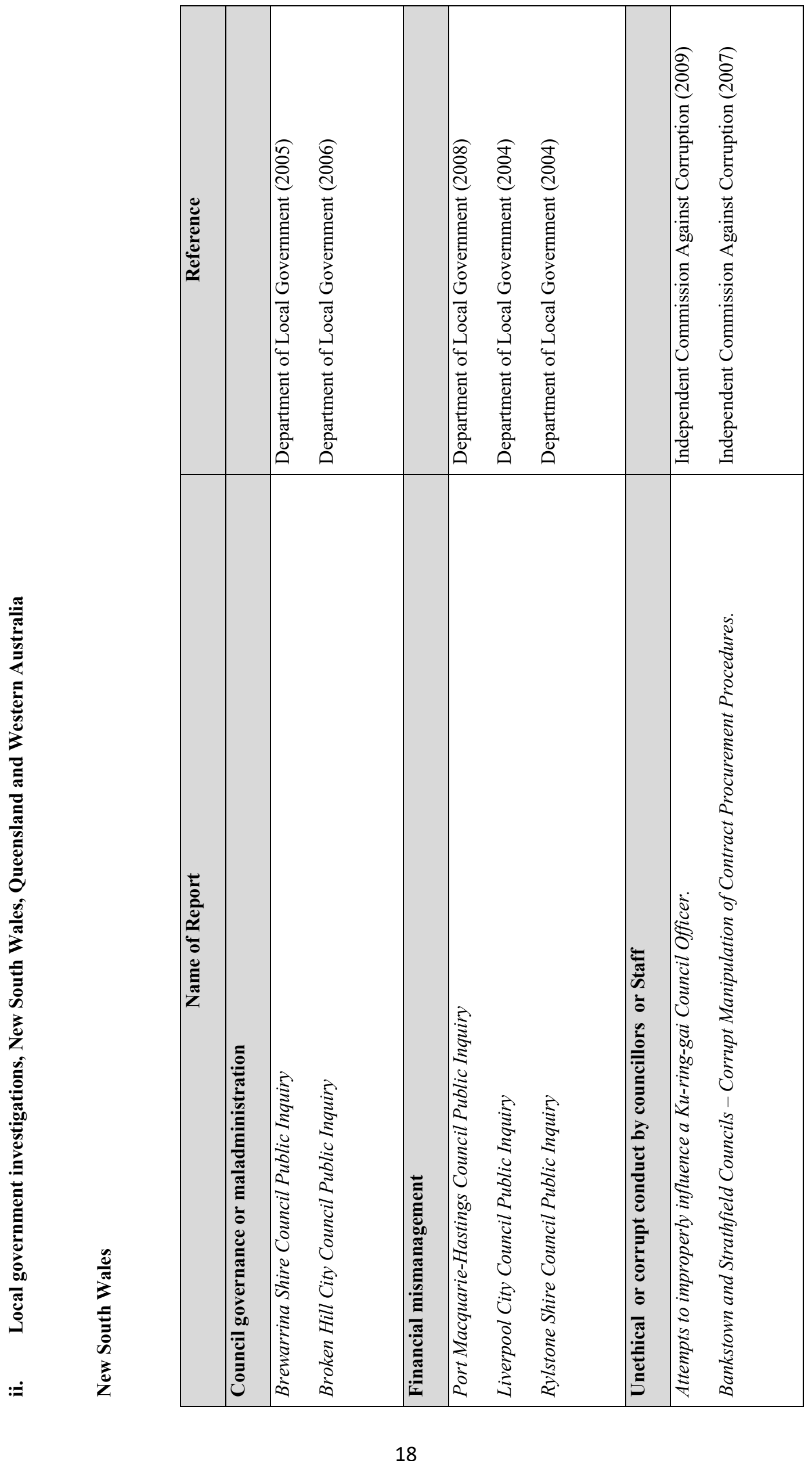



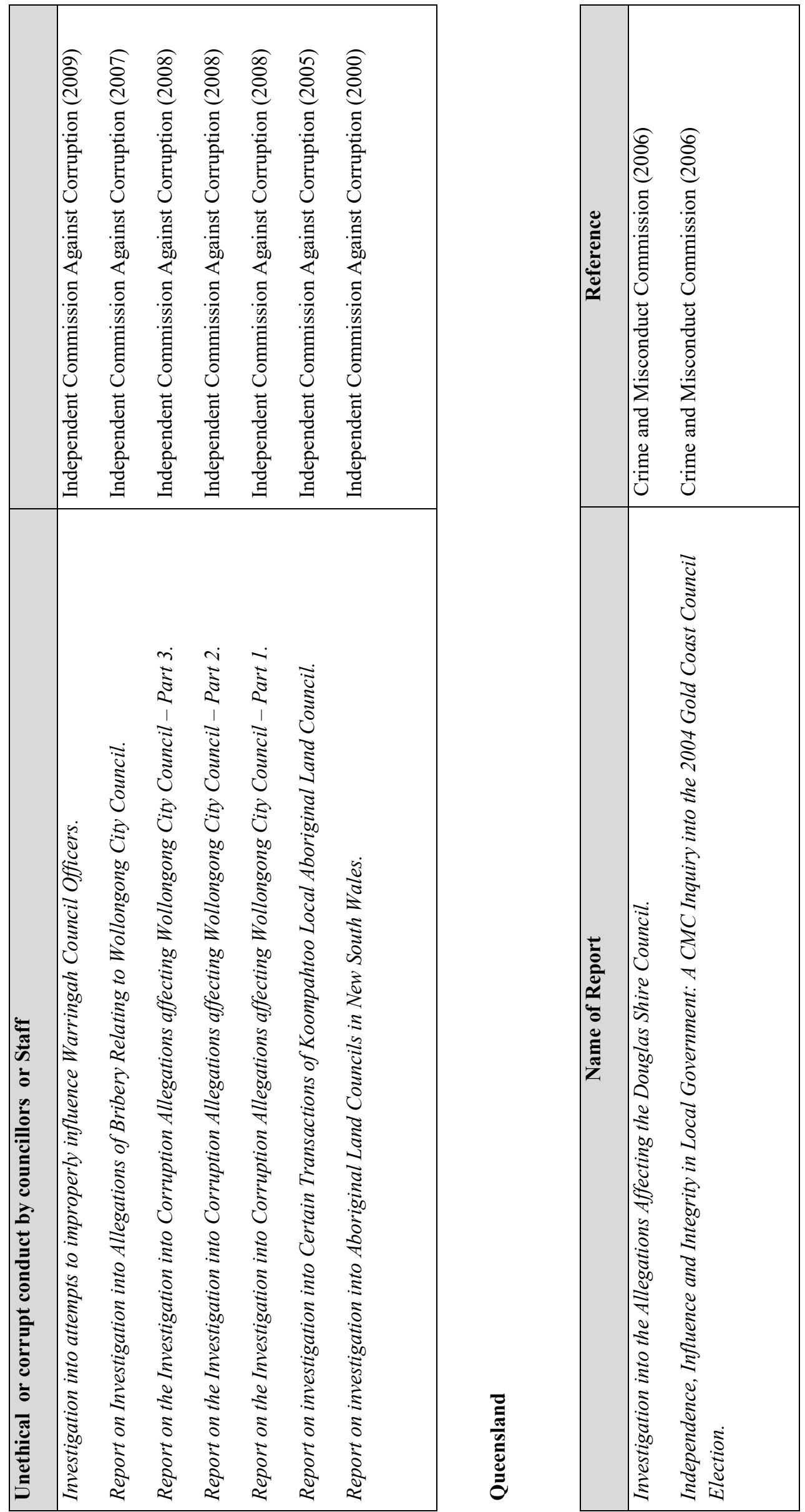

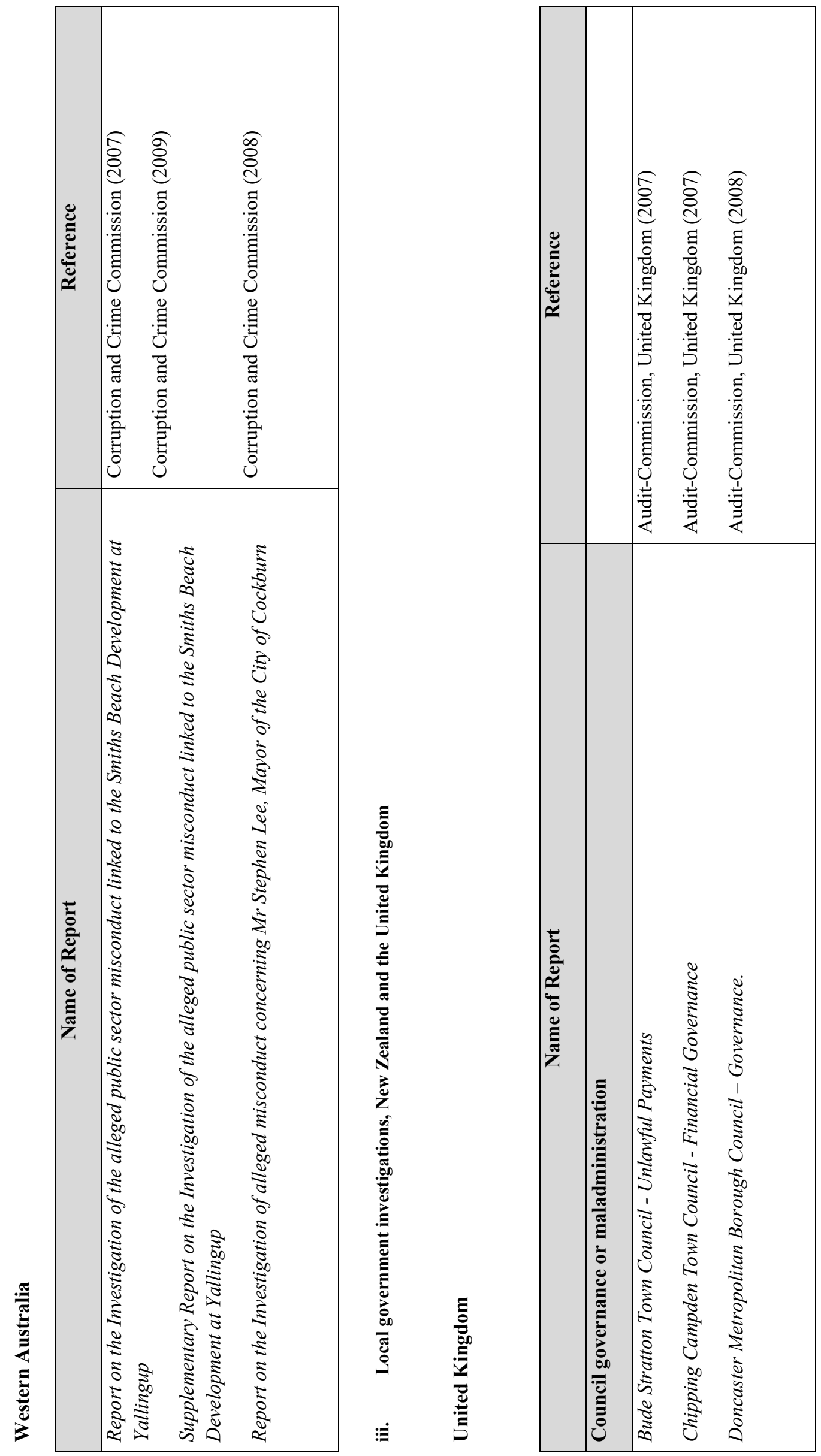

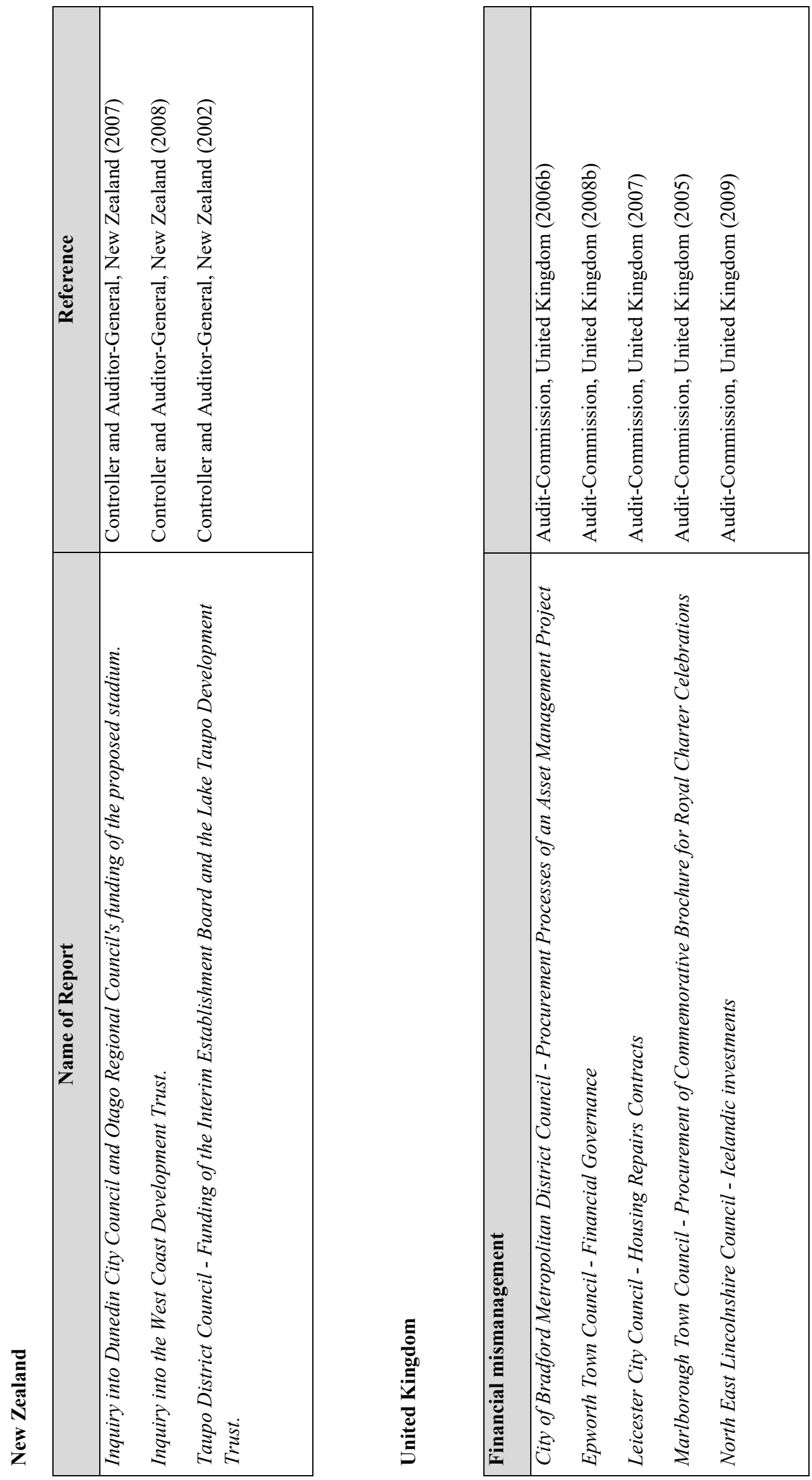


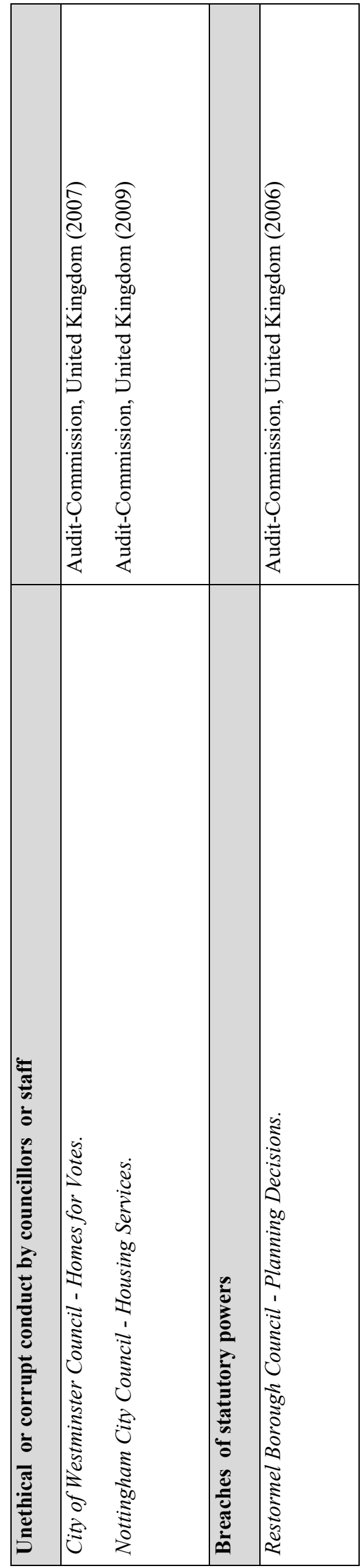

